\title{
A COMPARATIVE ECONOMIC STUDY ON TREATMENT OF OIL BASED FLUIDS BETWEEN KINGDOM OF BAHRAIN AND KINGDOM OF SAUDI ARABIA APPLIED ON THE PETROLEUM SECTOR
}

\author{
Nader Albair Fanous ${ }^{1}$, Alaa Abdullah Al-Sadiq ${ }^{2}$, Mariam Mohamed Jaffar Al Mowal ${ }^{3}$ \\ ${ }^{1}$ Faculty of Commerce,Ain Shams University. \\ ${ }^{2}$ Arabian Gulf University. \\ ${ }^{3}$ Institute of Environmental studies \& Research.
}

\begin{abstract}
$\underline{\text { Abstract }}$
This study deals fully with the comparison between the countries of Bahrain and Saudi Arabia in terms of the economic path and an understanding of the extent of the impact of this study on the oil sector. The study deals with an understanding of the different mechanisms of the impact of treatment of oil liquids on the economy of the two countries and how there can be different ways to support the process of oil recovery and treatment of oil liquids for both countries. The study attempts to shed light on the work mechanisms of both countries and understand these different paths that the two countries undertake financially to deal with this framework and provide the main needs completely locally and internationally. The theoretical framework is applied through presenting a group of previous studies in this field and knowing the importance of this process and the role played by both countries. The two countries are also compared to understand fixed plans and mechanisms to support this process and to know the most important factors affecting economically the process of treating oil liquids. I relied on the analytical approach to know the effects of oil-based liquids treatment between the Kingdom of Bahrain and the Kingdom of Saudi Arabia on the petroleum sector. Oyo and the most important challenges facing them, and the importance of establishing an infrastructure for waste oil management and knowing the large costs has been demonstrated, as well as the extent of the impact of the global economic framework and the impact of oil on the countries of Bahrain and the Kingdom of Saudi Arabia. The oil and gas industry, as well as how to benefit from nanotechnology, which has recently emerged in this field.
\end{abstract}

\section{$\underline{\text { Introduction }}$}

Although it is recognized that oil is not the only factor in development, it is still the most important resource and economic force that controls the development process in Arab oil producing countries and to a lesser degree in other Arab countries. Development experiences in the past two decades have shown that Arab oil has practiced, and still practices, direct and indirect effects on the factors that affect development in Arab countries and on economic integration and its incentives 
between them. Hence, knowledge of these effects in Arab oil and non-Arab countries is considered an urgent and important necessity. Significant, especially if we want to take into account the future prospects and its possibilities. The importance of oil for the oil countries comes through first its effective contribution to economic development through the hard currencies that oil revenues provide necessary to finance capital goods and consumption of services in the construction of a private industrial base refining and petrochemicals industry.

Evidence indicates that oil will remain a major role in defining development paths in the Arab producing countries. The main source of energy will remain, with the consequent increase in demand for it in world markets, and thus an increase in the production capacity of the Arab producing countries.

\section{$\underline{\text { Researsh Problem }}$}

However, there are variables and challenges, some of which are national or regional and the other international, affecting its importance as a commodity and an energy source on the one hand, and the importance of producing countries on the other hand. Attempting to anticipate the future of the oil sector is a difficult and difficult task due to the difficulty in predicting the stability of the global oil markets because of its influence by political factors Economic and difficult to quantify, which makes the process of foresight risky.

Drilling waste management is the necessary planning process for the collection, treatment and disposal of waste and oil liquids. The waste management process is a standard process for a long time, and there are big reasons that make the process of treating oil liquids a difficult process and need perfect planning, including organizational pressures that imposed large and more stringent controls, practices of treatment of oil liquids, environmental pollution trends, public health risks, increased costs and enormous costs that Relates to the future liability of this framework. In any case, the process of treating oil liquids is a common and acceptable part of good business management. In the event that an oil waste management infrastructure is in place, a comprehensive plan can save significant costs while ensuring that the best available options are used for oil liquids treatment operations. The comprehensive plans for waste management and treatment of oil liquids allow to think about the indirect and direct costs and to understand the extent of economic matters and their impact and the extent of the losses related thereto. There are additional costs associated with the selection of drilling fluids, and / or waste treatment, as comprehensive planning of drilling waste management provides an opportunity to address these costs and to find real alternatives to pursue 
these processes. The process of treating petroleum liquids is a comprehensive process that needs to be studied taking into account the potential cost in the long run. These costs include legal settlements, judgments, lawsuits, fines, or other legal regulations resulting from inappropriate practices to treat oil liquids. The matter may differ from country to country, but fines and penalties remain tens of thousands of dollars when violations become serious, or when lawsuits lead to settlements or rulings.

In this context, the operations of treating oil liquids are considered one of the most important economic frameworks in the field of waste management in the Kingdom of Saudi Arabia and the Kingdom as the economy of the Kingdom of Saudi Arabia and the State of Bahrain has achieved very strong growth rates during recent years benefiting from high oil prices and oil output, the strength of the private sector activity, and increased government spending, A number of local reform initiatives have been implemented. Also, high oil prices and increased oil production led to huge surpluses in the external account and public finances, while government debt fell to very low levels. The economic outlook remains favorable. However, the significant drop in oil prices since the summer of 2014 poses significant risks to the outlook. The economy of the Kingdom of Saudi Arabia and the State of Bahrain remains highly dependent on oil revenues to support growth, fiscal balance and external balance - more than $90 \%$ of fiscal revenues and $80 \%$ of export revenues come from selling oil. Hence, developments in the global oil market acquire central importance for economic prospects. Falling oil prices will have a direct negative impact on fiscal balances and the external account, and over time will likely slow growth.

One of the important things in drilling wells is choosing the location of the well, where drilling is the only way to ensure the presence of an oil trap, which requires accuracy in choosing the sites of drilling wells exploration and calendar field, and that the drilling determines the sequence of the layers that are penetrated and the thickness and characteristics and horizontal extension, and is important in determining The volume of oil stored in the well and its expected productivity, the expected recovery rate that is related to the type of the oil reservoir, and its natural energy that leads to the flow of oil and gas into the well cavity, all of which are practical indicators of the economic and technical feasibility of the oil field, and the location and depth of the well is determined according to its type, whether exploratory or Support that motivates to obtain more geological information, or to develop fields, and is conducted according to the types of stratified rocks, the nature of their cohesion together, approximate thickness estimates, the initial determination of the depth of wells, the diameters and lengths of drilling sections, and the types of lining tubes that are 
lowered after the completion of digging these sections. The types of drilling mud used in each section, and before drilling, the required measurements of electrical, radiant, acoustic and thermal, depths, and sections required to be tested are determined. Take samples from them, whether from crushed rocks, pulp, or liquids, to determine the qualities, porosity, and permeability of rocks, as well as choosing blast preventers to be installed on the wellhead.

This study deals in detail with the economic effects of treating petroleum liquids. The study deals with a comparative research for the countries of the Kingdom of Saudi Arabia and the State of Bahrain by presenting the most important policies that both of them follow in the course of treating oil liquids and the importance of these paths for both. The first chapter deals fully with the theoretical framework, as it includes the global framework for the oil economy, the process of treating oil liquids, the most important costs necessary for them, and the extent of the policies of the Kingdoms of Saudi Arabia and Bahrain to support the oil field. As for the second chapter, it deals with the theoretical framework for literary studies, follows the most important books and articles that touched on this topic and an understanding of the most important findings of previous studies.

\section{$\underline{\text { Research Objectives }}$}

To understand the economic path of the process of treating oil liquids and its importance.

To know the most important economic frameworks that Bahrain and Saudi Arabia are able to undertake in the field of treating oil liquids.

To understand the economic impact on Bahrain and Saudi Arabia during the process of treating oil liquids.

To make a comparison between the countries of Bahrain and Saudi Arabia in understanding the mechanisms of working on oil extraction and the treatment of oil liquids and the most important challenges facing them.

\section{Research Importance}

Study the economic impact if there are problems in the treatment of oil liquids and follow the path necessary to understand these problems.

Understand how drilling waste is managed as it is the planning process needed to collect, treat and dispose of waste and petroleum liquids.

Knowing the regulatory pressures that impose great controls on the treatment of oil liquids for both countries 
Understanding the importance of organizing an infrastructure for managing waste oil and knowing the big costs, while ensuring that the best available options are used for oil liquids treatment operations.

A comprehensive comparison study of the direct and indirect costs of the Kingdom of Saudi Arabia and the State of Bahrain in managing the treatment of oil liquids.

Clarify the monetary policy of the Kingdom of Saudi Arabia and the Kingdom of Bahrain and the extent of their interaction with the process of treating oil liquids.

To understand the global economic framework and the impact of oil on the states of Bahrain and the Kingdom of Saudi Arabia.

\section{$\underline{\text { Research concepts }}$}

The treatment of drilling scraps is a segmented process as it relies on primary and secondary treatment. The first stage of treatment is to remove the stage from the drilling fluid in order to recover the drilling fluid and reuse it. The solid waste discharge process that is separate from the oilbased drilling fluid occurs in the oil-based slurry tank. The oil content ranges from $15 \%$ to $20 \%$ after the initial treatment. Most regional emissions require an oil-based drilling country of less than $1 \%$ of the oil. As for the drilling site for the secondary treatment required for oilseeds, it depends on the requirements of the emission policy. It is important to realize that the primary purpose of secondary treatment is to achieve non-harmful treatment of this waste. There are technical indicators that can determine this, namely the oil content of the remains after treatment, as well as the efficiency of recovering the essential oil. The primary treatment equipment is a series of solid material control equipment. The secondary treatment equipment includes thermal absorption, solvent extraction, biological treatment, chemical washing, incineration and other technologies. There are secondary treatment methods that can be explained below:

Solids control equipment: This equipment is diverse and includes shakers, cyclones, and centrifuges. The drilling sites are fully prepared with this equipment according to the requirements of control and treatment.

Thermal adsorption: This technique separates and condenses most of the liquid phase oil in cutting holes during air heating conditions. During the thermal absorption process, the water will first evaporate as steam forms to reduce the boiling point of the oil. In this context, thermal adsorption occurs at a temperature that is less than the value of the evaporation of the oil accurately. The method of thermal absorption system requires cylindrical units that are heated depending on the heat 
resulting from heating the fuel. Also, this method requires screw type units and TCC units that are directly heated. These units reduce the oil content of solid residues to less than $1 \%$, and the oil can be recovered by precisely condensing.

Extraction with solvents: Supercritical fluids are important in terms of their use as extracts for cutting asphalt-based pits, where the supercritical fluid is a state present between gas and liquid. This potential has tremendous strength like gas and density soluble as a liquid as this process is done using supercritical CO2 technology. This method of carbon dioxide recovery technology is important in terms of mixing a waste oil-based drilling fluid and the oil is extracted into the supercritical fluid. After decompression, the oiler can be used, as the process should be carried out under a high pressure of 14.5 Mpa, and a relatively high temperature of $40^{\circ} \mathrm{C}$. In this context, high pressure and temperature are used for the supercritical carbon dioxide extraction technology, where a method has been developed to replace carbon dioxide with liquefied gas such as propane and butane, which is the process of extracting liquefied gas.

Bioremediation: This technique uses the benefit of degradation of living organisms and uses them to break down hydrocarbons in oil-based pits. This biological treatment includes compost, land cultivation and bioreactors. On the other hand, this includes harmless treatment for oil-based drilling parts, and biological treatment requires a different long treatment cycle while the rate of repair depends on the environment, oil-based drilling cuttings, and type of treatment. But before looking at the treatment process, external factors such as the ambient temperature and a large area of land must be verified, and they cannot restore energy and materials in the oil-based drilling parts.

In this context, the main way to get rid of oil-based drilling scraps can be understood, but treatment methods, government legislation, environmental standards, costs, and logistical services must be understood. Consequently, multiple treatment methods can be combined to improve the efficiency of oil-based treatment as well as meet the requirements of strict emission policy. For example, like Weiyuan and Changing in Sichuan, the shale gas development areas actually require "zero emissions". As a result, thermal absorption can be used to reduce the oil content of oil-based drilling parts and recover oil. On the other hand, hardening / fixing or incineration is used for the accurate disposal of solid waste. Before entering into processing operations, there must be a complete analysis of the oil-based drilling cut-off policy specifically in the oil production areas. For example, the discharge requirements in China for oil-based drilling sectors are classified into three levels: firstclass region (oil content is less than 1\%), second-tier region (oil content is less than 3\%) and thirdgrade region (oil content Less than $8 \%$ ). In this context, oil-based drilling parts can be emptied with 
permission, but in the Bohai Sea region, it looks different as they completely prevent the drainage process. There are some differences in the requirements for internal emissions, such as Sichuan Province policy as it does not significantly require emptying oil-based drilling parts. As for the US Environmental Protection Agency (USEPA) prohibits the launch of oil-based drilling rigs in all regions, while Brazil does not allow emissions based on oil-based drilling and low mineral oils, but they put in place clear policies and allow emptying enhanced mud based on IBAMA certified mineral oil. Consequently, there will be clear policies in terms of developing methods for treating oil-based drilling scraps based on several factors such as thermal absorption, solvent extraction, hardening or stabilization and bioprocessing. The complex structure of the oil-based drilling cutter and strict emission policies emphasize the accuracy of the process and the overall policies pursued by countries. So, the Middle East is almost the same as him in terms of increasingly applying these policies, as a few technologies can handle oil-based drilling scraps that are created in a variety of different conditions. World oil market prospect with reference to the Saudi \& Bahrain position and its Fiscal Politic. The global oil market ant its effect on Oil based liquid. It has been affected by conflicting factors over the past several years. Global oil demand has increased slightly over the past three years (by 2.5 million barrels per day), driven by demand in non-OECD countries. In the economic field, the major interruptions in oil production in Libya and Iran have led to a decrease in output by more than two million barrels per day in several quarters of years compared to production levels at the end of the year 2010. At the same time, oil production in the United States has increased by more than two million barrels per day since End of the year, 2010 and rose the number of output in the Kingdom of Saudi Arabia, and supplies from countries such as Iraq, Kuwait, and the United Arab Emirates increased. These developments generally led to a significant stability in oil prices, ranging from $\$ 100$ to $\$ 120$ a barrel between 2011 and August 2014. However, prices fell by more than\% 25 since the beginning of September, 2014, at the time of writing this report, it had reached $\$$ 75 a barrel, i.e. its lowest levels since September. In the short term, while demand for oil is expected to increase with the expected improvement in the global economy, there remains an atmosphere of uncertainty on the supply side. These include an atmosphere of uncertainty about how the violence that Iraq is currently experiencing will affect its future production path and uncertainty about the situation surrounding Ukraine. Even in the midst of deepening turmoil, oil production in Libya recovered from June 2014 onwards, but the path to recovering future output remains surrounded by uncertainty due to the ongoing turmoil. Supply cuts in Nigeria, South Sudan and Venezuela can negatively affect oil production. In addition, falling oil prices may continue to harm investments in 
oil production capacity from regions with high production costs (Report) (IEA, 2014a). However, if U.S. production continues to exceed expectations, or the political situation in Libya and Iraq stabilizes, or the sanctions imposed on Iran have been eased, as oil supplies to the global market may exceed expectation. On the demand side, while continued weak demand from OECD countries is likely to continue, higher consumption in non-OECD countries is expected to lead to continued strong global demand in the medium term. The expected increase in global oil demand of 7.7 million barrels per day by 2019 is mainly driven by the request of non-OECD countries, where it is expected to increase by $19 \%$ or 8.6 million barrels per day. The demand growth of non-members of the organization in the past few years was driven by the rapid growth in the BRICS countries (Brazil, Russia, India, China and South Africa).

\section{$\underline{\text { Literature Review }}$}

Various studies have touched upon an accurate understanding of the nature of oil fluid processing and knowledge of the extent to which these oil operations relate to economies, both in the Middle East or on the global scale. These studies have used various analyzes taking into account the cases of countries in which these tires are fully implemented. Among the studies that touched on linking the process of energy consumption to economic growth is a study that dealt with an understanding of the systematic review of the relationship between energy consumption and economic growth in the countries of the Gulf Cooperation Council. This study was conducted by (AlKhars et al., 2020), which analyzed the literary surveys that exist on the relationship of energy consumption to economic growth in the Gulf countries and include (Saudi Arabia, the United Arab Emirates, Bahrain, Qatar, Oman and Kuwait). The study examined approximately 59 articles published in 18 magazines covering the period 2006-2019. This study collected all available articles in two different categories: The first category included studies analyzing the energy-growth relationship at the individual country level. While the second category included studies of relationship analysis at the level of multiple countries. The study thoroughly concluded that $18 \%$ of the observations supported the growth hypothesis, $26 \%$ supported the hypothesis of conservation, $43 \%$ supported the hypothesis of feedback, and 13\% supported the neutral hypothesis imposed by the researcher. These results were fully analyzed, as the researcher emphasized that energy policies in the Gulf Cooperation Council countries are largely based on supply and continuous availability to expand and grow their industrial and development activities. The researcher also reached the adoption of sustainable development in the Gulf countries through the expansion of renewable energy technology in order to help the field of energy and private supplies, including operations for the treatment of oil liquids and extraction and 
others.

As for a study (Baridor, 2016), it confirms that the petroleum industry is facing problems related to waste disposal and treatment on oil fields resulting from oil drilling and production. The study attempts to shed light on ways to manage waste around oil in the Niger Delta region. The study relied on traffic according to a comparative economic assessment of the method of treating oilfield waste for decision-making. The study provides a model on the best way to handle production operations through the maximum benefit on investment and the use of sampling techniques in selecting 45 oil companies. The study relied on these forty questionnaires (40 questionnaires). The completed questionnaires were sorted and analyzed using descriptive statistics of tables, percentages and bar graphs. The study was able to evaluate the methods of treating oilfield waste from an operational, environmental and economic point of view while the net present value (NPV). The study confirmed a high level of negative impact of the management of these wastes in the oil fields because of the weak use of the methods that were adopted with a large shortage in the activities of organization, exploration and production in the petroleum industry. Finally, the study concluded with introducing new improvements in the field of oil and waste treatment based on the approved methods and the enforcement of existing laws that direct the regulation of industry activities.

In a study by (Emmanuel and Nosa, 2019) whose objective was to assess the environmental and biological degradation of drilling waste: a case study of drilling cuttings from oilfield wells Ologbo in Edo State, Nigeria. The study tries to confirm the extent of understanding the waste path of the oilburdened pits, as it was considered a significant threat. The study tries to shed light on the problem of oil drilling drilling through the production line in Nigeria, where nearly 3900 billion barrels of drill cuts were produced in four thousand and fifty-four meters of drilling operations on the beach. The study followed these guidelines set by the authorities in Nigeria in terms of discharging drilling parts into the environment without first verifying zero or minimum impacts through conducting environmental impact assessment studies and the environmental assessment report. The study followed the process of biological decomposition, which is divided into components such as fatty acids, carbon dioxide and water in order to understand the nature of this degradation of oil pollutants. The study concluded that the drilling holes emanating from these oilfield sites are not safe for disposal and that there are serious restrictions that oil production and processing operations should follow before disposal. Otherwise, appropriate sanctions must be applied. The study recommended that the oil exploration industries adhere strictly to the procedures and instructions described for waste management in exploration for exploration and the prohibition of the use of toxic oil-based 
mud by oil exploration companies in Nigeria. In this context, it is recommended to treat wastes resulting from oil activities properly before actually disposing of them. Based on this study, waste is seen as raw materials that can be reused and can be reused in more than one field.

In a study by (Cutler, 2001), he referred to an evaluation of the costs of energy processes and systems and oil treatment by analyzing net energy by comparing the amount of energy delivered to society through the energy system used directly and indirectly. The study tries to shed light on the

method of aggregation, which has critical effects on the results of the analysis. In its content, the study relies on showing the heat equivalent of the corrected EROI for oil extraction in the United States of the same general pattern. The study indicated significantly that quality corrections have important impacts on the results of energy analyzes in general. Also, the general decline in the EROI for oil extraction in the United States may indicate significantly that depletion has raised energy costs from oil extraction. The study stressed that there is no true measure of the quality of oil and gas resources, but there are various resources and indicators describing the deterioration, including the decrease in the size of the field and the exhaustion of natural driving mechanisms and others, which affects oil processing operations economically significantly.

In a study by (Mortadha et al., 2020) on the use of nanotechnology and its economic and environmental impact on the oil processing process, petroleum materials and various industries. The study examined the impact of nanotechnology recently on the oil and gas industry such as drilling fluids and improved oil recovery in addition to other applications. The study attempted to shed light on how to treat drilling fluids in petroleum materials by reviewing the successful applications of nanotechnology and the challenges associated with it in the Middle East in order to fully study to understand the nature of these materials and their use in petroleum processing. The results of the study showed that the oil and gas industry can rely on nanotechnology as very promising results have emerged in terms of its performance and effectiveness in the field of treatment of petroleum liquids and the importance of using nanoparticles despite the presence of some challenges such as economic feasibility and its impact on health, safety and the environment. The study also recommends the use of the nanoscale field because it showed a significant improvement in the applications of the petroleum industry and treatment of oil liquids as it greatly affects the rheological and filtration properties of drilling fluids as well as improving the thermal stability of drilling fluids in general. This may be a reason for its use in Arab countries in one way or another in order to reduce economic 
costs, as a significant increase in oil recovery was observed when the nanoparticles were applied to apply enhanced oil recovery and reduced oil viscosity.

\section{$\underline{\text { Research Hypothesis }}$}

Treatment of oil liquids has an economic impact on the country's path and oil extraction.

The work appears clearly prominent and positively affects the course of treatment of oil liquids in the Kingdom of Saudi Arabia more than the state of Bahrain.

Economically appropriate solutions can be found in the long run in treating oil liquids for Bahrain and Saudi Arabia.

It is easy to track the economic impact if there are problems in the treatment of oil fluids and to monitor the economic situation fully

Table (1) Shows Drilling Waste Management Approaches (Drilling Waste Management Approaches).

\begin{tabular}{|c|c|c|}
\hline I. Haste Minimizution Approaches & II - Keyde or Keuse Approaches & III - Lipposal Approacher \\
\hline 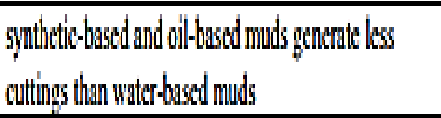 & 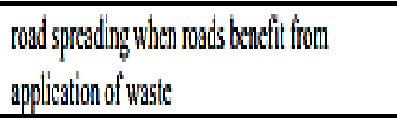 & land gpendidng or land larning \\
\hline willed tubing ditiling & 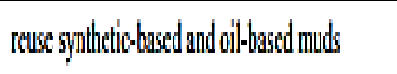 & codd spresding \\
\hline dirationalhorizontal dilling & usc clanded cutting for fill or cover material & burial in onsite pit or offsita landilil \\
\hline use of lese toric components ad dddive for mods & 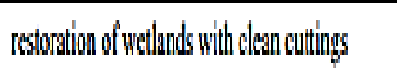 & discharge to owan \\
\hline \multirow[t]{4}{*}{ aid ditiling } & 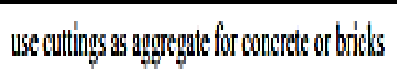 & alt caven disposal \\
\hline & themal tratment with fludid rawery & undergenound ijaction \\
\hline & & thermal trastment \\
\hline & & 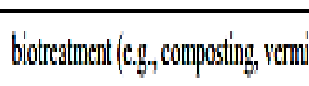 \\
\hline
\end{tabular}

\section{$\underline{\text { Methodology Framework }}$}

This research is a descriptive research and the main research objective is to show A Comparative Economic Study On Treatment Of Oil Based Fluids Between Kingdom Of Bahrain And Kingdom Of Saudi Arabia Applied On The Petroleum Sector. Based on examining only a portion of the total population, selected in a way that reflects the structure of the whole. In achieving objectives through this research, the researcher employed the questionnaire survey - as a means of gathering information. This suggests that attitudes are mental positions that cannot be observed directly, but 
must be analyzed based on research results. The fact that attitudes are learned affirms they will be affected by information and experience. (Kotler and Keller, 2009).

Moreover, this chapter aims at analyzing the data that was collected from the research sample, testing the hypotheses, and reaching the results. The research is designed to combine both theoretical and empirical studies using different measures in measuring the variables included in the research hypotheses according to the types of the variables.

The research depends on practicing data financial analysis between companies in Bahrain \& Saudi Arabia. To complete the research requirements the researcher choose 2 oil and petroleum companies from KSA and Bahrain to check the impact of focusing on Oil liquids in both countries - Petro Rabigh (KSA) and The Oil \& Gas Holding Companies (Bahrain) - and the below ratios will be used in this analysis
1- Liquidity Ratios
2- Profitability Ratios
3- Efficiency Ratios
4- Debit and Equity Ratios

\section{Study community}

This study deals fully with the comparison between the countries of Bahrain and the Kingdom of Saudi Arabia in terms of the economic path and an understanding of the extent of the impact of this study on the oil sector, especially Oil-fluid treatment. The study sample consisted of 30 single samples to show the comparative economic study on treatment of oil based fluids between Kingdom of Bahrain and Kingdom of Saudi Arabia applied on the petroleum sector. A financial analysis of the financial statements of a Saudi company and a Bahraini company, in order to compare the economic outcomes in oil liquids processing operations.

Rabigh Refining \& Petrochemical Company (KSA)

The Oil \& Gas Holding Company B.S.C. (c) (Bahrain)

\section{Data Collection}

The study used the methodology of economic analysis by presenting Saudi and Bahraini models in dealing with the treatment of oil liquids. This methodology is based on the framework of an economic analysis of the two countries in the framework of dealing with the treatment of oil liquids, as it relies on a test in the field of petroleum and identifying the most important economic frameworks resulting from this test. 


\section{Rabigh Refining \& Petrochemical Company (KSA)}

Rabigh Refining \& Petrochemical Company (Petro Rabigh) is a Saudi Arabia-based company which produces and markets refined hydrocarbon and petrochemicals. The company was a joint venture between Saudi Aramco and Japan's Sumitomo Chemical which is now publicly held. It is traded on the Saudi Stock Exchange.

Petro Rabigh's operates a 400,000-barrel (64,000 m3) capacity refinery located in Rabigh, Saudi Arabia, which produces naphtha, kerosene, gasoline, diesel and fuel oil. (Mouawad, 2008)

The company produces 140 million barrels of petroleum products and 5 million tons of petrochemical products every year.

The company held its initial public offering in January 2008.[2][3][4] Ownership of the company is $37.5 \%$ to Saudi Aramco, $37.5 \%$ to Sumitomo Chemical, and $25 \%$ to the public.

Construction of second phase completed in 2016 and production began in 2017 (Henni, 2009) .

It is considered the first producer of many petrochemical products and the only producer of propylene oxide in the Middle East (Petro, 2008).

In December 2020, the boards of directors appointed Othman Ali Al-Ghamdi as a board member and CEO, effective from Jan. 1, 2021, after the resignation of the CEO Nasser Damsheq Al-Mahasher (Petro, 2020)

The Oil \& Gas Holding Company B.S.C. (c) (Bahrain)

The Oil \& Gas Holding Company B.S.C. (c) (nogaholding) was established by Royal Decree No. 77 for the year of 2007, promulgated on August 15, 2007

The company is the investment and development arm of the National Oil \& Gas Authority (NOGA) and plays a fundamental role in the execution of the strategic plans of the authority and stewardship of the government's investment in The Bahrain Petroleum Company (Bapco), The Bahrain National Gas Company (Banagas), The Bahrain National Gas Expansion Company (BNGEC), The Bahrain Aviation Fuelling Company (Bafco), The Bahrain Lube Base Oil Company (BLBOC), the Gulf Petrochemical Industries Company (GPIC), Tatweer Petroleum, Skaugen Gulf Petchem Carriers Company (SGPC) and Bahrain LNG Company (BLNG)

Nogaholding creates value from existing portfolio companies and by enlarging the portfolio. At the time the company was formed in 2007 the portfolio comprised four companies, one wholly owned and three partly owned.

The company believes that joint venturing is the route to long-term sustained generation of shareholder wealth. Thus post its establishment, four additional companies, one wholly owned and 
three partly owned, were added to nogaholding's portfolio. (The Oil \& Gas Holding Company website).

Below is the financials performance analysis.

\section{1- Liquidity Ratios}

Table (2) Shows Liquidity Ratios for Petro Rabigh (KSA) and The Oil \& Gas Holding (Bahrain) Companies

\begin{tabular}{|l|l|l|l|l|l|l|}
\hline Liquidity Ratios & & 2015 & 2016 & 2017 & 2018 & 2019 \\
\hline \multirow{3}{*}{$\begin{array}{l}\text { Current Ratio } \\
\text { Quick Current }\end{array}$} & Bahrain & 0.50 & 0.50 & 0.59 & 0.59 & 0.41 \\
\cline { 2 - 7 } & KSA & 3.89 & 3.90 & 4.21 & 3.66 & 3.38 \\
\cline { 2 - 7 } & Bahrain & 0.40 & 0.37 & 0.45 & 0.46 & 0.29 \\
\cline { 2 - 7 } & KSA & 3.51 & 3.41 & 3.68 & 3.33 & 3.11 \\
\hline
\end{tabular}

The above table shows the Current Ratio and Quick Current Ratio as part of Liquidity ratio and this is for Petro Rabigh (KSA) and The Oil \& Gas Holding (Bahrain) Companies for past 5 years (20152019) and the researcher concluded that:

For Current Ratio: the range of The Oil \& Gas Holding (Bahrain) was between (0.41-0.59) and Petro Rabigh (KSA) was between (3.38-4.21)

\section{2- Profitability Ratios}

Table (3) Shows Profitability Ratios for Petro Rabigh (KSA) and The Oil \& Gas Holding (Bahrain) Companies.

\begin{tabular}{|c|c|c|c|c|c|c|}
\hline Profitability Ratios & & 2015 & 2016 & 2017 & 2018 & 2019 \\
\hline \multirow{2}{*}{ Gross Profit Ratios } & Bahrain & 0.08 & 0.08 & 0.10 & 0.06 & 0.05 \\
\hline & KSA & 0.15 & 0.21 & 0.27 & 0.20 & 0.25 \\
\hline \multirow{2}{*}{$\begin{array}{l}\text { Operating Profit } \\
\text { Ratios }\end{array}$} & Bahrain & 0.03 & 0.02 & 0.02 & 0.02 & 0.01 \\
\hline & KSA & 0.09 & 0.18 & 0.10 & 0.05 & 0.05 \\
\hline \multirow{2}{*}{ Net Profit Ratios } & Bahrain & 0.02 & 0.02 & 0.01 & 0.02 & 0.00 \\
\hline & $\mathrm{KSA}$ & 0.10 & 0.14 & 0.10 & 0.04 & 0.06 \\
\hline \multirow{2}{*}{$\begin{array}{l}\text { Return on Assets } \\
\text { Ratios }\end{array}$} & Bahrain & 0.01 & 0.01 & 0.01 & 0.01 & 0.00 \\
\hline & KSA & 0.08 & 0.09 & 0.08 & 0.03 & 0.03 \\
\hline \multirow{2}{*}{$\begin{array}{l}\text { Return on Equity } \\
\text { Ratios }\end{array}$} & Bahrain & 0.05 & 0.07 & 0.05 & 0.06 & 0.01 \\
\hline & KSA & 0.12 & 0.14 & 0.13 & 0.05 & 0.07 \\
\hline
\end{tabular}

The above table shows the Profitability Ratios and this is for Petro Rabigh (KSA) and The Oil \& Gas Holding (Bahrain) Companies for past 5 years (2015-2019) and the researcher concluded that. 
For Gross Profit Ratios: the range of The Oil \& Gas Holding (Bahrain) was between (0.05-0.10) and Petro Rabigh (KSA) was between (0.15-0.27)

As the Profitability ratios assess a company's ability to earn profits from its sales or operations, balance sheet assets, or shareholders' equity and profitability ratios indicate how efficiently a company generates profit and value for shareholders and from the historical performance data we can say that Petro Rabigh (KSA) company has the ability to generate earnings relative to its revenue, operating costs, balance sheet assets, or shareholders' equity over time more than The Oil \& Gas Holding (Bahrain) based on the previews data.

\section{3- Efficiency Ratios}

Table (4) Shows Efficiency Ratios for Petro Rabigh (KSA) and The Oil \& Gas Holding (Bahrain) Companies

\begin{tabular}{|l|l|c|c|c|c|c|}
\hline Efficiency Ratios & & 2015 & 2016 & 2017 & 2018 & 2019 \\
\hline \multirow{3}{*}{ Inventory Turnover } & Bahrain & 11.92 & 10.87 & 9.62 & 12.06 & 9.50 \\
\cline { 2 - 7 } & KSA & 11.75 & 7.81 & 8.22 & 11.14 & 8.78 \\
\hline \multirow{2}{*}{$\begin{array}{l}\text { Notes Receivable } \\
\text { Turnover }\end{array}$} & Bahrain & 0.59 & 0.70 & 0.64 & 0.77 & 0.53 \\
\cline { 2 - 7 } & KSA & 1.76 & 1.50 & 1.92 & 1.61 & 1.36 \\
\hline $\begin{array}{l}\text { Fixed Assets } \\
\text { Turnover }\end{array}$ & Bahrain & 0.69 & 0.65 & 0.84 & 0.83 & 0.54 \\
\cline { 2 - 7 } & KSA & 2.09 & 1.31 & 1.57 & 1.84 & 1.40 \\
\hline \multirow{2}{*}{ Assets Turnover } & Bahrain & 0.54 & 0.54 & 0.63 & 0.64 & 0.46 \\
\cline { 2 - 7 } & KSA & 0.82 & 0.64 & 0.75 & 0.74 & 0.56 \\
\hline
\end{tabular}

The above table shows the Efficiency Ratios and this is for Petro Rabigh (KSA) and The Oil \& Gas Holding (Bahrain) Companies for past 5 years (2015-2019) and the researcher concluded that:

For Inventory Turnover: the range of The Oil \& Gas Holding (Bahrain) was between (9.5-12.06) and Petro Rabigh (KSA) was between (7.81-11.75).

As The efficiency ratio also known as activity ratios is used to analyze how well a company uses its assets and liabilities internally. An efficiency ratio can calculate the turnover of receivables, the repayment of liabilities, the quantity and usage of equity, and the general use of inventory and machinery and from the historical performance data we can say that Petro Rabigh (KSA) company can measure the performance of a company's short-term or current performance more than The Oil \& Gas Holding (Bahrain) based on the previews data. 


\section{4- Debit and Equity Ratios}

Table (5) Shows Debit and Equity Ratios for Petro Rabigh (KSA) and The Oil \& Gas Holding (Bahrain) Companies

\begin{tabular}{|c|c|c|c|c|c|c|}
\hline $\begin{array}{l}\text { Debit and Equity } \\
\text { Ratios }\end{array}$ & & 2015 & 2016 & 2017 & 2018 & 2019 \\
\hline \multirow{2}{*}{$\begin{array}{l}\text { Total Debits to Total } \\
\text { Assets }\end{array}$} & Bahrain & 0.73 & 0.61 & 0.79 & 0.67 & 0.78 \\
\hline & KSA & 0.37 & 0.34 & 0.31 & 0.37 & 0.33 \\
\hline \multirow{2}{*}{$\begin{array}{l}\text { Total Debits to Total } \\
\text { Equity }\end{array}$} & Bahrain & 4.14 & 4.84 & 4.28 & 4.06 & 5.74 \\
\hline & KSA & 0.56 & 0.52 & 0.51 & 0.68 & 0.70 \\
\hline \multirow{2}{*}{$\begin{array}{l}\text { Total Current Debits } \\
\text { to Total Assets }\end{array}$} & Bahrain & 0.42 & 0.36 & 0.43 & 0.39 & 0.38 \\
\hline & KSA & 0.16 & 0.13 & 0.12 & 0.16 & 0.18 \\
\hline \multirow{2}{*}{$\begin{array}{l}\text { Total Long Term } \\
\text { Debits to Total Assets } \\
\text { (resource of finance) }\end{array}$} & Bahrain & 0.45 & 0.46 & 0.48 & 0.45 & 0.49 \\
\hline & KSA & 0.28 & 0.27 & 0.26 & 0.30 & 0.27 \\
\hline \multirow{2}{*}{$\begin{array}{l}\text { Interest } \\
\text { Ratio } \\
\end{array}$} & Bahrain & 5.76 & 5.81 & 5.84 & 6.08 & 3.77 \\
\hline & KSA & 30.09 & 49.22 & 56.23 & 26.97 & 29.73 \\
\hline
\end{tabular}

The above table shows the Debit and Equity Ratios and this is for Petro Rabigh (KSA) and The Oil \& Gas Holding (Bahrain) Companies for past 5 years (2015-2019) and the researcher concluded that: For Total Debits to Total Assets: the range of The Oil \& Gas Holding (Bahrain) was between (0.610.79) and Petro Rabigh (KSA) was between (0.31-0.37)

\section{Conclusion}

The detailed soybean OBM has a Bingham plastic rheological model with low yield point and gel quality, mud property alluring for tempestuous stream at low siphon pressure for viable gap cleaning. Also, The soybean OBM has moderately high thickness and can be expanded with densifiers to alluring qualities during equal flowing thickness (ECD) forecasts so as to get a fruitful penetrating activity. It seems that the filtration misfortune property of the figured soybean OBM contrasted well and diesel OBM with channel cake normal for slender and delicate wanted during boring tasks. The broad survey over the ongoing examinations of nanoparticles inside the oil and gas industry has indicated that nanotechnology has as of late rose as an appealing subject of exploration and numerous investigations have demonstrated promising outcomes regarding their exhibition and adequacy. These promising outcomes are because of the unmistakable properties of nanoparticles. In spite of the high capability of utilizing nanoparticles, there are a few difficulties, for example, their monetary possibility and their effect on HSE. In light of the exhaustive writing audit, the accompanying ends were made, as the most generally examined nanoparticles that indicated noteworthy improvement for the various applications over the oil and gas industry were discovered 
to be the nanosilica $\left(\mathrm{SiO}_{2}\right)$ trailed by aluminum oxide $\left(\mathrm{Al}_{2} \mathrm{O}_{3}\right)$, which proposes their high potential in being applied in the field. Also, the examined nanoparticles have indicated a noteworthy positive effect on both the rheological and filtration attributes of penetrating liquids just as improving the warm solidness of boring liquids. Finally, treatment of oil liquids has an economic impact on the country's path and oil extraction. The vast majority of the explored nanoparticles brought about upgrading the mechanical properties of concrete just as giving a superior control to the set time.

\section{$\underline{\text { Recommendations }}$}

1. Moreover, a huge increment in oil recuperation was seen when nanoparticles were applied for EOR application on a research center scale by methods for wettability adjustment and oil thickness decrease.

2. In spite of an enormous number of research facility scale examinations distributed in the writing, just four documented preliminaries with promising outcomes were distributed apparently recommending the requirement for more field preliminaries.

3. In light of the difficulties talked about, more exploration ought to be directed so as to diminish the expense of creating nanoparticles.

4. Distinguishing the methane delivered in oil activities will be significant for confirming administrators' reports of this dreary and scentless gas that is undetectable to the unaided eye. Better information about the conditions under which methane is delivered thusly should bring about new working conventions to decrease GHG emanations to guarantee change occurs.

5. As related gas can keep on introducing difficulties when it isn't erupted and rather accidentally leaks out or is purposefully released. Such criminal outflows and venting, separately, are developing issues that are as of now underreported, making it difficult to tell whether flare-decrease advancements lessen methane spills and venting.

6. Innovations will be required, including progressing observing that utilizes far off detecting advances, similar to the European satellite-based SCIAMACHY sensor and the satellites presently being created in France, Germany, and Japan.

7. Detecting the methane delivered in oil activities will be significant for checking administrators' reports of this lackluster and scentless gas that is imperceptible to the unaided eye.

8. Better information about the conditions under which methane is delivered thusly should bring about new working conventions to lessen GHG outflows to guarantee change occurs. 


\section{REFERENCES}

Baridor Odagme. (2016). Economic Analysis of Oilfield Waste Management Systems in the Niger Delta (A Case Study). The Journal of Scientific and Engineering Research 3(4):367-374 . July 2016.

Cutler J. Cleveland. (2001). Net energy from the extraction of oil and gas in the United States. Energy 30 (2005) 769-782. Center for Energy and Environmental Studies and Department of Geography, Boston University, 675 Commonwealth Avenue, Boston, MA 02215, USA. Received 6 January 2001.

Drilling Waste Management Planning Guide. MI SWASO. Customer Focused, solutions-driven.

Emmanuel Esosa Imarhiagbe and Nosa Omoregbe Obayagbona. (2019). Environmental Evaluation and Biodegradability of Drilling Waste: A Case Study of Drill Cuttings from Ologbo Oilfield Wells at Edo State, Nigeria. Submitted: February 27th 2019Reviewed: July 16th 2019Published: November 19th 2019. DOI: 10.5772/intechopen.88612.

Henni, Abdelghani (April 20, 2009). "Aramco signs MoU with Sumitomo for Petro Rabigh". Arabian Oil and Gas. Retrieved 10 January 2010.

Kotler, P. and Keller, K. (2009). Marketing management. 13th ed, London: Person Education ltd. Mohammed AlKhars, Fazlul Miah, Hassan Qudrat-Ullah and Aymen Kayal. (2020). A Systematic Review of the Relationship Between Energy Consumption and Economic Growth in GCC Countries. Amorin, R., Dosunmu, A. and Amankwah, R. K. (2015), "Economic Viability of the Use of Local Pseudo-Oils for Drilling Fluid Formulation”, Ghana Mining Journal, Vol. 15, No. 2, pp. $81-90$.

Mortadha T. Alsaba, Mohammed F. Al Dushaishi \& Ahmed K. Abbas. (2020). A comprehensive review of nanoparticles applications in the oil and gas industry. Journal of Petroleum Exploration and Production Technology volume 10, pages1389-1399(2020). Available at: 
https://link.springer.com/article/10.1007/s13202-019-00825-z.

Mouawad, Jad (January 20, 2008). "The Construction Site Called Saudi Arabia". The New York Times. Retrieved 10 January 2010.

Petro Rabigh appoints new CEO as Nasser Al-Mahasher resigns". Arab News. 2020-12-08. Retrieved 2020-12-08.

petro Rabigh ipo subscription exceeds sar 2.4 billion in two days". AlBawaba.com. January 7, 2008. Retrieved 11 July 2008.

Study in Arabic: Ahmed Al Darwish, Nayef Al Ghaith, Alberto Bihar, Tim Calin, Pragyan Deeb, Amjad Hijazi, Badamja Khandallal, Malika Pant, and Hunan Co. (2015) Saudi Arabia: Addressing Emerging Economic Challenges to Maintain Growth. P: 1. ISBN: 978-1-49838-2045 .

The Oil \& Gas Holding Company website: https://www.noga.gov.bh/noga/companydetails.aspx?id=0.

Zhiqiang Huang, Xu Ziyang, Yinhu Quan, and Hui Jia. (2018). A review of treatment methods for oil-based drill cuttings. Article (PDF Available) in IOP Conference Series Earth and Environmental Science 170(2):022074 . 


\section{المستخلص - (المي}

تتتاول هذه الدراسة بشكل كامل المقارنة بين دولتي البحرين والمملكة العربية السعودية من حيث المسار الاقتصادي وفهم مدى تأثير هذه الدراسة على قطاع النفط. تتناول الدراسة فهم الآليات المختلفة لتأثير معالجة التحنة السوائل النفطية على اقتصاد البلدين وكيف يمكن أن تكون هناك طرق مختئ مختلفة لدعم عملية استخراج النفط

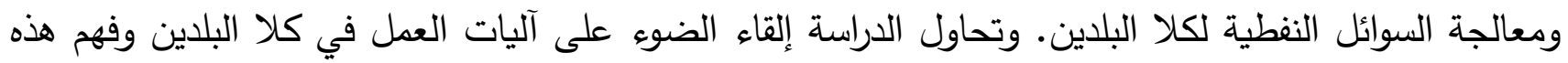

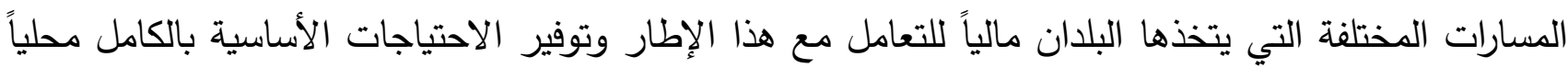

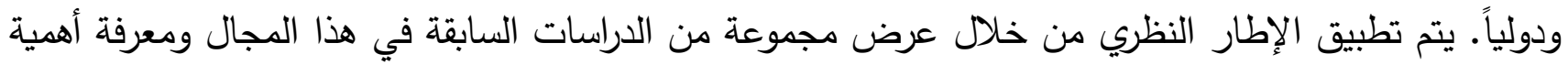
هذه العملية والدور الذي يلعبه كلا البلدين. كما يتم مقارنة البلدين لفهم الخطط والآليات الثابتة لدعم هذه العملية

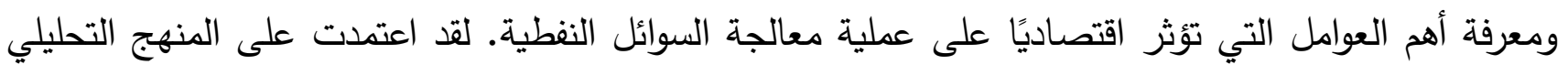

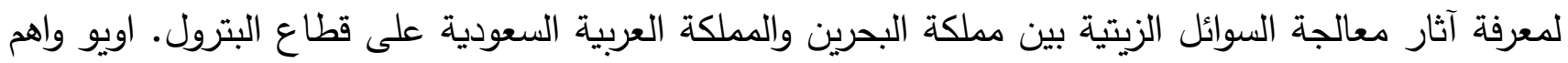

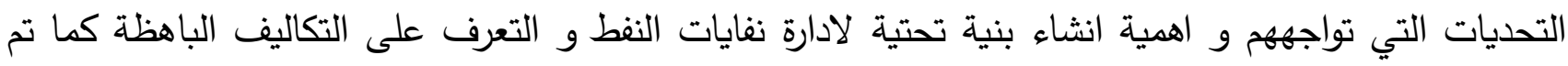
توضيح ددى تاثير الاطار الاقتصادي العالمي و اثر النفط على الدول البحرين والمملكة العربية السعودية. صناعة النفط والغاز وكيفية الاستفادة من تقنية النانو التي ظهرت مؤخراً في هذا الهجال. 